\title{
БЕЛОМОРСКИЕ КЛЕЙМА
}

Статья посвящена исследованию карсикко (от кар. karsia 'обрубать ветки', карзать) - деревьев-знаков, распространенных преимущественно в зоне северных хвойных лесов и имеющих разнообразные функиии. В данном случае речь пойдет о клеймах, то есть о семейных и родовых знаках, применяемых в качестве знаков собственности и вырезаемых на деревьях, когда необходимо обозначить охотничью тропу (путик) с настороженньми на ней силками или гранииу промысловых угодий отдельной семьи, родового коллектива. Кроме того, так могли отмечать деревья в местах ночевок в лесу или вблизи промысловых изб, на тонях, то есть местах вытягивания невода и т. д. Любой знак на дереве, как правило, имел помимо практического также и магическую, охранную функиию (ср. ночевка в лесу, в незнакомом месте, вдали от дома).

Статья, описывающая две поездки на побережье Белого моря, делится на две связанные между собой части, первая из которых посвящена непосредственно клеймам. Карельские клейма, о которых идет речь, практически не изучены: помимо одной статьи Д. Золотарева, приводящего материал с крайнего севера карельской территории, им не посвящено каких-либо научных работ. Знаки собственности несомненно имеют давнюю историю и неоднократно видоизменялись. Тем не менее, автор делает попытку сопоставить имеющиеся сведения и вывести некоторые закономерности относительно фигуры ромба, зафиксированной в клеймах на севере Карельского берега.

Второй сюжет касается обычая врезки в деревья медных складней и деревянных крестов-иконок (впрочем, крест могли просто вырезать в коре дерева), которые до середины XIX века изготовлялись в старообрядческом Даниловском скиту (Выгореция), и в крестьянской среде, помимо основного своего места на божнице в избе, выполняли в основном роль апотропея, охраняя развилки и перекрестки дорог и троп, гранищы поселений и другие средоточия «нечистой силь»», нейтрализуя ее влияние на людей. Одним, а, может быть, и основным таким местом было кладбище, где как в деревья, так и в намогильные столбиь и кресты ранее врезались иконки с изображением креста и, чаме всего, с так называемой головой Адама на горе Голгофа, символизирующей первое с момента сотворения мира захоронение смертного человека. Следует заметить, что помимо иконок-крестиков (а в иных местах и икон с изображением одноименного с умершим святого) на намогильных сооружениях, а также рядом с могилами на деревьях могли вырезать родовой знак умершего с его персональным клеймом.

Конкка Алексей Петрович - к.и.н., старший научный сотрудник, Институт языка, литературы и истории Карельского научного центра РАН (185910, Республика Карелия, г. Петрозаводск, ул. Пушкинская, 11). Эл. почта: alekkonkka@outlook.com; ORCID: 0000-0002-6837-5656 
Ключевые слова: знаки собственности, охотничьи и рыболовные клейма, фигура ромба, деревянные кресты-иконки, Карельский берег Белого моря

Ссылка при цитировании: Конкка А.П. Беломорские клейма // Вестник антропологии, 2022. № 1. С. 150-160.

DOI: $10.33876 / 2311-0546 / 2022-1 / 150-160$

(C) A.P. Konkka

\section{WHITE SEA STAMPS}

The article is devoted to the study of karsikko (from the Karelian "Karsia" - "to chop off branches") - sign trees that can be seen mainly in the zone of northern coniferous forests and have various functions. Stamps are family and ancestral marks used as signs of ownership and carved on trees to designate a hunting trail with snares on it or the border of the fishing grounds of a family or a tribal group. Trees could be marked in places of overnight stays in the forest or near fishing huts, on patrimonial grounds, etc. Any sign on a tree usually also has a magical function protecting those who spend the night in the forest, in an unfamiliar place, away from home.

The article describes two trips to the White Sea coast and consists of two related parts, the first one being devoted directly to the stamps. The Karelian stamps have received very little attention in the scientific literature: apart from one article by D. Zolotarev, who described data from the extreme north of Karelia, no works have been devoted to them. Property marks have a long history and have undergone various changes. Nevertheless, the author compares the conclusions and identifies some patterns regarding the rhombus figure used in the stamps in the north of the Karelian coast.

The second narrative is based on the tradition to embed copper folds and wooden cross-icons into the trees (although the crosses could be carved in the tree's bark). These artifacts were made in the Old Believers' Danilovsky Skete (Vygoretsia) until the middle of the 19th century. Among peasants, apart from belonging to the shrine in the hut, they played the role of an apotrope, guarding the forks and crossroads of roads and paths, the borders of settlements, and other places where "evil spirits" were concentrated, neutralizing their influence on people. Earlier, icons with the image of a cross and often with the so-called Adam's Skull on Mount Golgotha, symbolizing the first burial of a mortal person since the world's creation, were embedded in crosses and trees at the cemeteries. In addition to the cross-icons (and in some places images of the saint of the same name with the deceased), the patrimonial mark of the deceased with his personal stamp could be carved on the grave structures and the trees next to the graves.

Keywords: property marks, hunting and fishing marks, stamps, rhombus figure, wooden cross-icons, Karelian coast of the White Sea

For Citation: Konkka, A.P. 2022. White Sea Stamps. Herald of Anthropology (Vestnik Antropologii) 1: 150-160.

Author Info: Konkka, Aleksi P. - PhD in Hist., Senior Researcher, Institute of Language, Literature and History of the Karelian Scientific Center of the Russian Academy of Sciences (Petrozavodsk, RF). E-mail: alekkonkka@outlook.com 
В июле-сентябре 2014 года состоялись наши поездки в пос. Чупа Лоухского района Карелии. В июле после проведения конференции «Природное и культурное наследие Белого моря: перспективы сохранения и развития», ее участники побывали в бухте Корабельной в проливе Глубокая салма напротив о. Пежостров на археологических раскопках энеолитических поселений, проводимых Надеждой Лобановой. Здесь же, на морской террасе с редким сосновым лесом, в пределах нескольких сотен метров от берега моря вдоль троп и в лесу поблизости от них было зафиксировано 32 затеси (некоторые еще со следами топора), в основном на больших и старых, высохших соснах. Затесы были сделаны на еще растущих деревьях. Таким образом, возраст этих зарубок мог быть очень почтенным и, исходя из предыдущего экспедиционного опыта в этих широтах, мог доходить до 200 лет и старше. Речь идет именно о старых затесах на деревьях, к слову скажем, что никаких свежих порубок в этом районе обнаружено не было. Они были разной формы и размера: от небольших 7 х 5 см или 10-12 длиной и 4-5 см шириной до 20 х 10 см соответственно. Один из затесов у комля дерева был довольно крупным: 60 на 40 см, самый же большой достигал 1,5 метров в длину (в высоту от земли) и 30 см в ширину. В основном затесы были сделаны на уровне груди или головы взрослого человека, однако пять затесок находились у самой земли или на комлях сосен. Формы затесов были в основном в виде вытянутых вдоль ствола лент разной длины с зауженными концами, но было также несколько практически круглых и прямоугольных зарубок, в двух случаях встретились затеси в виде клина или треугольника (широкой стороной к земле). Следует заметить, что первоначальные формы некоторых затесок были частично деформированы в период зарастания их еще при росте деревьев и края их были неровными, так, что очертания их можно было определить лишь предположительно.

Особенный интерес представляли затесы на соснах № 6 и 25, обнаруженные ранее директором Чупинского морского яхт-клуба Юрием Рыбаковым. На этих затесах были вырезаны прекрасно сохранившиеся клейма - родовые или семейные знаки или знаки собственности, издревле используемые местным населением. На ровной поверхности практически прямоугольной формы затеса № 6 были вырезаны два знака высотой около 10 см: первый, напоминающий заглавную букву «Ч» и рядом справа $-\diamond$, то есть ромб, но перечеркнутый в верхней своей части горизонтальной линией (рис. 1). Затес был сделан на высоте около 180 см от земли. Затес № 25 представлял собой глубокую зарубку на уровне $170-175$ см от земли в высохшей сосне, высотой 55 и шириной 15-17 см. В верхней части затеса был вырезан более уплощенный и меньший по размеру, в сравнении с первым клеймом, ромб. Ромб соединялся с косым «рубежом» (по старой терминологии рубежами называли поперечные линии на клеймах) несколько косо вправо от основания ромба идущей короткой линией. Под этой конструкцией в затесе был вырезан еще один косой «рубеж» параллельно первому (рис. 2).

На этом же дереве сбоку был сделан затес $(45$ х 30 см) в виде треугольника с выступом внизу, который обычно называют «полкой» (рис. 3), так как подобные «полки» на деревьях в некоторых местах используют для временной установки на них иконок и свечей. С правой стороны «полки» затес продолжался в другой плоскости, образуя между полкой и продолжением затеса «гребень», то есть выдающийся углом наружу правый край «полки». Следует заметить, что на соседнем дереве была такая же «полка», только меньших размеров. 
Каково же было предназначение этих затесов на деревьях? Простая зарубка на дереве, как это показывают карельские и финские материалы, равна по своему значению с определенным образом обработанным деревом-карсикко, у которого отрубается вершина, обрубаются в определенных местах ветки или в стволе которого вырезаются знаки. Сделать затеску - значит сделать из дерева дерево-знак, когда оно превращается в обработанный, освоенный (в сравнении с диким природным окружением) человеком предмет, часто имеющий магическое значение. Человек вдали от поселений, особенно в незнакомой местности, делал себе карсикко, вырубал метки на деревьях, отмечал дорогу - осваивал окружение, одновременно сотворяя для себя охранителей от враждебных сил стихии. Со временем мировоззрение менялось и знаки приобретали все более практическое значение, однако тот факт, что они сосредотачиваются в основном вокруг временного или постоянного жилища человека, все еще говорит об их защитной роли. От освоения территории вообще и от родовых знаков, легко было перейти к знакам собственности, каковыми и являлись вырезанные на зарубках № 6 и № 25 клейма. Клейма, как известно, могли использоваться в качестве подписи, для маркировки определенных предметов промысла и быта, домашних животных, земельных участков, а также охотничьих угодий, например, путиков, то есть охотничьих троп с настороженными на них силками на дичь. Путики передавались по наследству и часто обозначались родовым или семейным клеймом охотника, которое вырезалось в начале путика и далее через определенное расстояние на деревьях. Идет ли здесь речь о начале путиков, землевладении определенного рода (или родов), границе охотничьих владений (проходившей между двумя знаками собственности на деревьях) или это были знаки собственности владельцев соседних морских тоней, нам не удастся узнать ранее, чем в архивах найдутся документы по этому поводу. Тем не менее, я сделал попытку найти хоть какие-нибудь общие сведения. В основе наших клейм, если не считать «букву» Ч, лежит ромб. Я изучил известные в литературе рисунки клейм карел, лопарей, поморов и русских Архангельской губернии: карельские (Золотарев 1924), лопарские клейма (85 штук), собранные Н. Харузиным (Харузин 1890: 256); лопарские клейма (340 клейм) из собрания Я. А. Комшилова (Комшилов, 1926), 136 клейм из русских волостей Поморья, Холмогор, Шенкурска, 31 лопарское клеймо, 106 карельских знаков, которые «взяты из решений волостных судов и книг договоров Корельских волостей Архангельской губернии» (Ефименко 1874).

Из всей массы изданных рисунков клейм у саамов и русских не нашлось ничего похожего на ромбы. Клейма Кестенгской волости Золотарева оказались частично сходными с лопарскими, а частично уже более позднего типа, напоминающие инициалы. Лишь только одно клеймо из дер. Коккосалма (последнее в списке на с. 145) напоминало ромб, который в данном случае представлял из себя две «скобы», посредине которых была вертикальная черта: 〈〉 («скобы» у Золотарева ближе к сердцевине, чем здесь). Однако у Ефименко, в его собрании карельских клейм, обнаружились интересные детали. Карельское клеймо под номером 197 можно интерпретировать как два соприкасающихся ромба перечеркнутые посередине поперечной линией (с другой стороны и как две «скобы», посредине которых стоит косой крест X, но сама конструкция уже очень близка к перечеркнутым ромбам, как и наш ромб на затесе № 6). Клеймо под номером 288 представляет собой два косых креста ХХ поставленных вплотную друг к другу, что можно интерпретировать как фигуру ромба с отростками с обеих сторон. Клеймо же под номером 226 неоспоримо представляет собой два отдельных ромба, соединенных фигурой простого креста (рис. 5). 


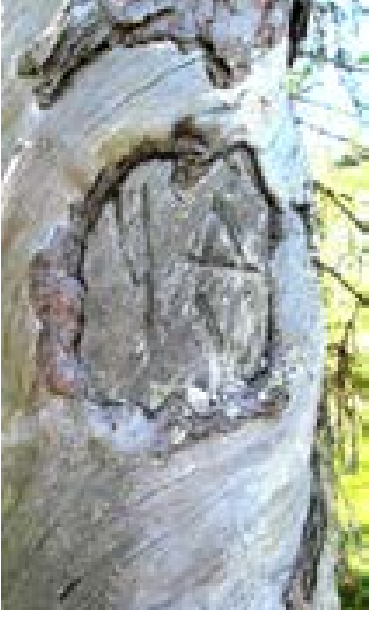

Рис. 1. Знаки

собственности на тропе в Корабельной бухте (фото автора, 2014).

Fig. 1. Property signs on the trail in Korabelnaya Bay (photo by the author, 2014).

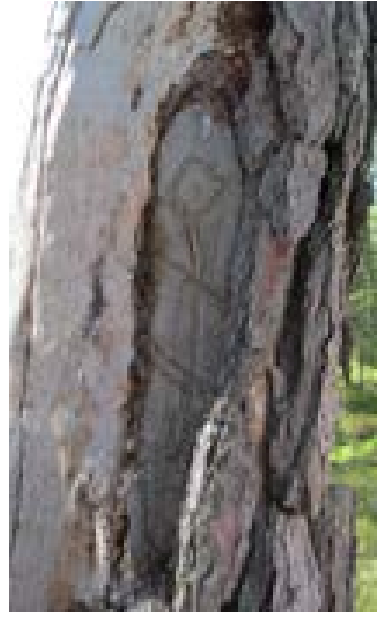

Рис. 2. Клеймо и "полка" на другой стороне деревакарсикко в Корабельной бухте (фото автора, 2014). Fig. 2. A stamp and a "shelf" on the other side of a karsikko tree in Korabelnaya Bay (photo by the author, 2014).

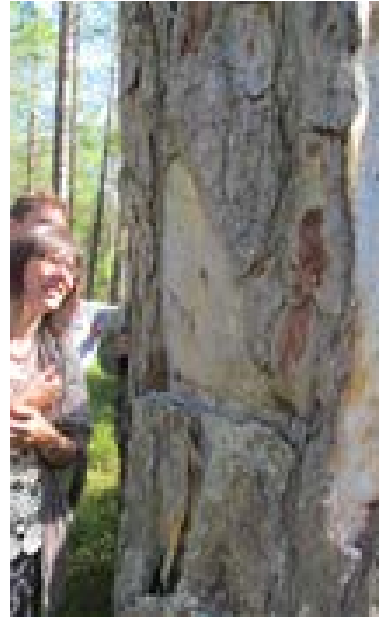

Рис. 3. Клеймо и "полка" на другой стороне деревакарсикко в Корабельной бухте (фото автора, 2014) Fig. 3. A stamp and a "shelf" on the other side of a karsikko tree in Korabelnaya Bay (photo by the author, 2014).
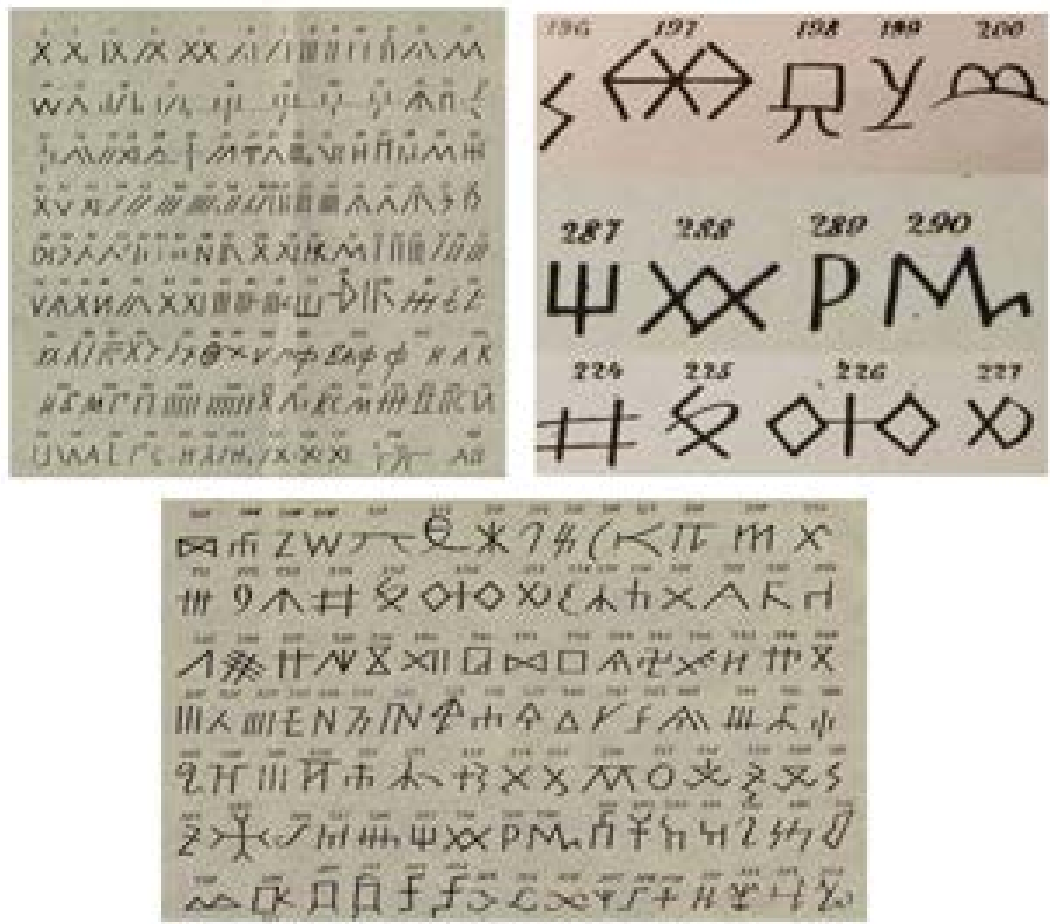

Рис. 4-6. Знаки собственности русского населения Архангельской губернии (Ефименко, 1874, Приложение).

Fig. 4-6. Property signs of the Russian population of the Arkhangelsk province (Efimenko 1874, Appendix). 
Таким образом, на основе имеющегося материала, можно сделать вывод, что фигуры ромбов в основе клейм на Северо-Западе России явление редкое и встречается только в карельских клеймах. К сожалению, П. Ефименко не оставил нам указаний из каких волостей он получил те или иные знаки собственности. Тем не менее, есть вероятность, что изыскания в документах ближайшей Керетской волости могут дать первые результаты, далее следует только расширять круг поисков. Так, два ромба классической формы $\diamond$, один из которых с дополнительными прямыми штрихами-отростками по углам, были обнаружены мной в 1979 г. среди других вырезанных на деревьях клейм в часовенной роще дер. Суднозеро, бывш. Вокнаволоцкой волости Кемского уезда, известной тем, что там еще в начале XX века проводились жертвоприношения животных. Фигура ромба с «рожками» (как на правой стороне клейма № 220 собрания Ефименко, см. рис. 6) присутствует среди карельских клейм в опубликованном Н. Лавонен документе из Государственного архива Архангельской области (Лавонен 1989: 45).

Дополнительным подтверждением тезиса о карельских корнях фигуры ромба можно считать обнаружение клейма, во многом идентичного знаку в Корабельной бухте, в часовенной роще дер. Бирючёво Ленобласти. Бирючёвская роща, вероятнее всего, наиболее старое культовое место локальной группы тихвинских карел-старообрядцев (фото 7-8). Что же касается клейма «Ч», то подобные «буквы» (больше в виде «У») встречаются среди карельских клейм как у Золотарева, так и у Ефименко.

Предположение о родовых знаках или знаках собственности на деревьях в Корабельной бухте подтверждается также фотографиями, полученными от Юрия Рыбакова из местечка Пелека (Пелег) южнее карельской деревни Соностров. Здесь тропы были проложены между морскими губами, что давало возможность не выходя в открытое море (особенно осенью во время сильных ветров), рыбачить (при наличии лодки) в соседних губах. Собственно, та же ситуация была и на тоне Иваньковской, откуда тропа ведет в губу Летнюю. На Пелеке найденные клейма располагались вдоль тропы. Одно из них по своей структуре сходно с вытянутым в стороны W, a также со знаком треугольника в разных вариациях известным как по карельским, так и по русским клеймам Архангельской губернии (рис. 9).

На втором клейме (кажущемся нам довольно свежим) косой крест вместе с буквенным обозначением может означать как клеймо, так и магический знак. Третье клеймо, напоминающее буквы, вырезанные вдоль ствола дерева: НИ І отличается от набранных здесь знаков тем, что «Н» и «И» написаны слитно и имеют общую вертикальную линию (рис. 10).

Примеры подобных знаков имеются как среди карельских, лопарских, так и клейм русского населения Архангельской губернии. Еще один затес со знаками довольно сильно зарос, но там, по моему мнению, прослеживаются части двух ромбов, между которыми находится вертикальная черта (клеймо вырезано вдоль ствола дерева). Интересно, что первое и третье клейма вырезаны на деревьях, в которых рядом со знаками вырублен «гребень» (рис. 9).

Что касается ромбовидных фигур, то они довольно часто встречаются в вепсской и карельской вышивке (а также в карельской резьбе по дереву), начиная со Средневековья. В том числе в фитоантропоморфных фигурах, соединяющих в себе растительные и антропоморфные мотивы. Особенно интересна форма изображения головы антропоморфной фигуры, чаще всего это именно ромб. «У этих фигур... голова вышита в виде 

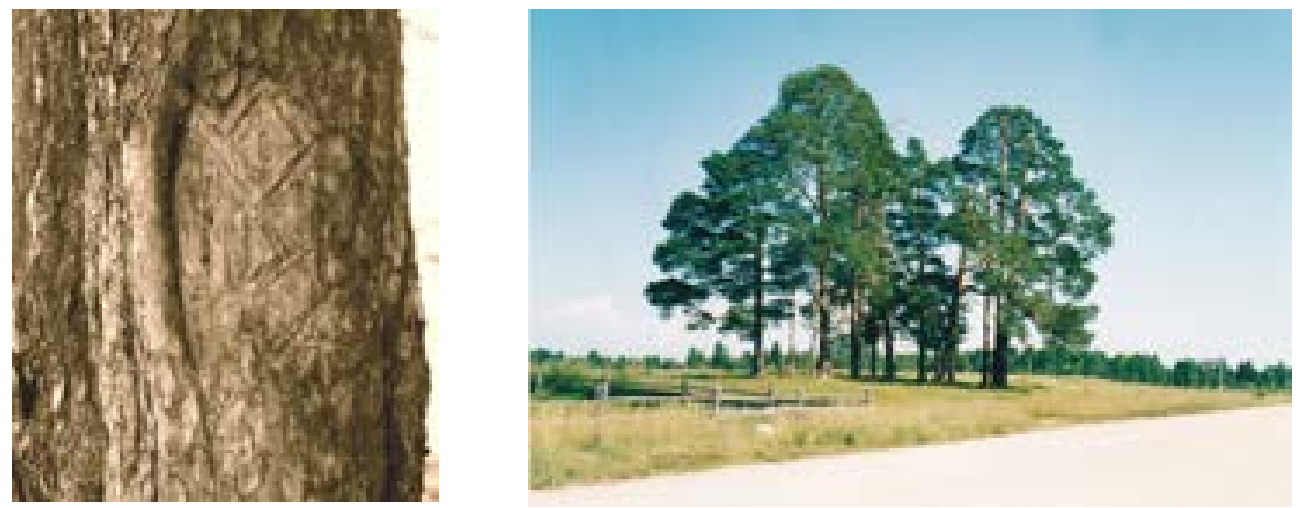

Рис. 7-8. Клеймо на дереве и общий вид Бирючёвской рощи, где некогда стояла kellä (часовня) (фото автора, 2004).

Fig. 7-8. A stamp on a tree and the general view of the Biryuchevskaya grove, where the kellä (chapel) once stood (photo by the author, 2004).

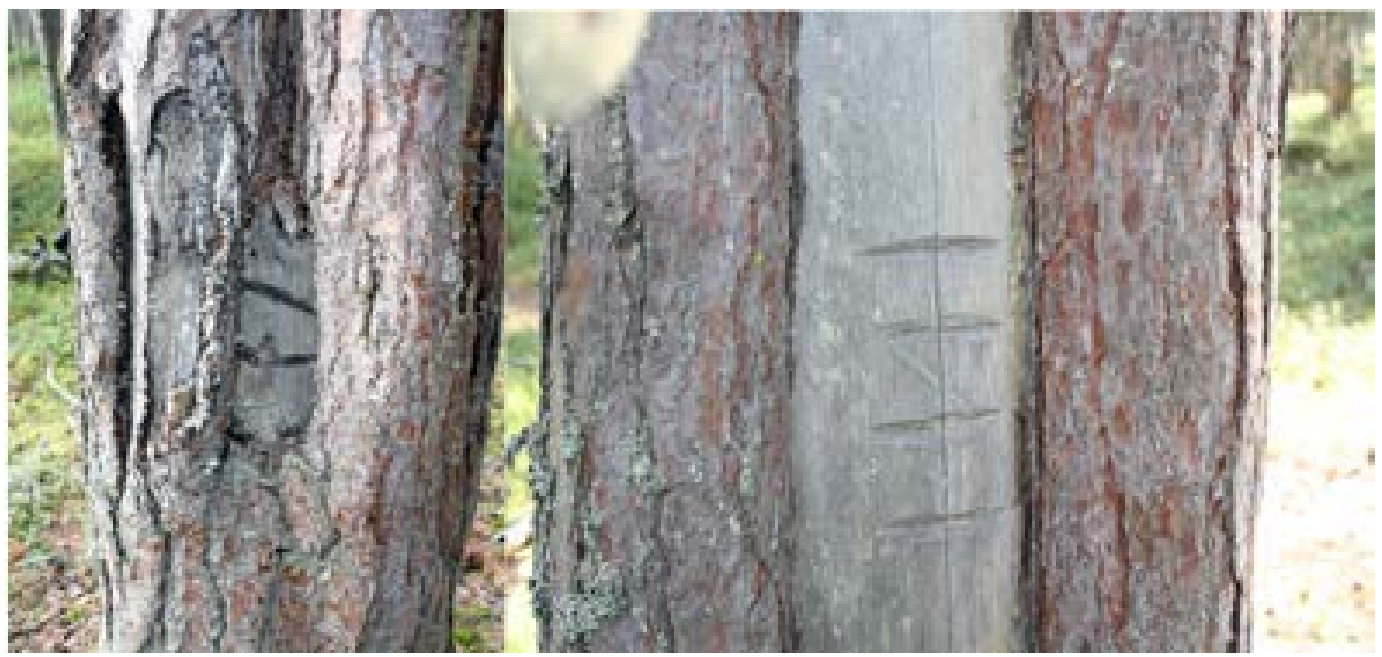

Рис. 9-10. Клейма, вырезанные вдоль троп на мысу Пелека (фото Ю. Рыбакова).

Fig. 9-10. Stamps carved along the trails at Peleka Cape. Photo by Y. Rybakov.

крупного ромба с многочисленными линиями-«лучами» на внешних краях» (Косменко 2002: 125. Ромбы в вышивке вепсов: 131-132, 118-119, 126-127; карел: 186, 188, 190, 197-198, 203). Широко представлены ромбы также в карельской резьбе по дереву. В известных работах финских архитекторов Ю. Бломстедта и В. Суксдорфа «Карельские постройки и формы декора» и «Народное зодчество и орнаментальные формы в Карелии по обе стороны границы» У. Ульберга, А. Тавастстьерны, Я. Кекконена, вышедших по следам экспедиций рубежа веков в среднюю и южную Карелию (Blomstedt ym. 1900; Ullberg ym. 1929) представлено более сорока рисунков строительных конструкций и предметов быта, в декоре которых используются ромбовидные формы. Это наличники, перила балконов, спуски, ветреницы и полотенца на крышах, столбы амбаров, намогильные столбцы, прялки, рубели, столы. Причем ромбы присутствуют не только в орнаментах, но и в конструкциях предметов (напр. в навершиях прялок и 
антропоморфных фигурах на ветреницах $)^{1}$. Особенно интересна ветреница на доме из дер. Мууанто (волость Суйстамо, Северное Приладожье), верхняя часть которой представляет собой схематизированную человекоподобную фигуру, выполненную из двух ромбов - маленького и большого вытянутого под ним (рис. 9).

Подобные антропоморфные изображения на севере Карелии встречаются также на могилах и на деревьях-карсикко на кладбищах. Здесь стоит упомянуть деревянную фигурку на домовине («гробнице») в дер. Хайколя Калевальского района (рис. 10), «ветреницу» на кресте в олонецкой дер. Нурмолицы (рис. 11) и вырезанное в дереве человекоподобное изображение на кладбище карельской дер. Куйваярви (Суомуссалми) (рис. 12). Такого же типа изображение было вырезано в стволе ели на старом кладбище Куусикко в дер. Панозеро на р. Кеми. Что касается ромбической формы головы, то здесь вероятна связь с восточными финно-уграми и другими народами уральской семьи, один из основных вариантов орнамента которых, а именно приобского, пятого типа сибирского орнамента, выделенный С. В. Ивановым, представлен в Историко-этнографическом атласе Сибири. Помимо приобского, ромбы представлены также в северносибирском, саяно-алтайском, нижнеиртышском и иртышско-алтайском типах орнамента (Историко-этнографический... 1961: 425, 427).

В сентябре мы отправились с Юрием Рыбаковым в губу Иваньковскую, где существует тоня такого же названия. То же название имела и старообрядческая пустынь, место которой было обнаружено ЮР в августе месяце 2014 года. Тропа на скит начиналась, собственно, с открытого недавно лабиринта на берегу. Иваньковская пустынь находилась вблизи Старушечьих озер, богатых кумжей. Направление из губы Иваньковской в целом на юг. Расстояния небольшие, в пределах километра-двух. Из Иваньковской губы идут две основные тропы: на Старушечьи озера и в губу Летнюю. Вдоль троп, а также вне их, в радиусе 50-70 метров от тоневой избы на деревьях (на соснах, а в низинах кое-где и на елях) сделаны разнообразные затесы и зарубки. Иногда они совершенно явственно обозначают тропу, иногда же идут одна за другой, насколько хватает деревьев. Здесь, в губе Иваньковской, картина уже несколько иная, нежели в Корабельной бухте: много зарубок сделано на довольно тонких деревьях, они менее четкие и, скорее всего, часть из них относительно недавняя. Лес также другой: растут лиственные виды: береза, рябина, а по берегам Старушечьих озер и кустарники. Тем не менее и здесь встречается старые сухостойные сосны с зарубками. Размеры от 10 х10 до больших затесов (от 20 х30 на березе до 60 х50 на сухостое). В целом же узкие 25-30 см в длину и 7-10 см в ширину. Формы разнообразные: одни длинные и узкие, другие круглые, третьи расширяющиеся книзу, встречались и форменные зарубки, когда топором вырублена часть дерева, как будто кто-то начал его рубить. По тропе на Иваньковскую пустынь я насчитал 10 затесов, еще 9 вокруг жилья, из них два было на березах. По тропе на запад от

${ }^{1}$ То же можно сказать и относительно ромбических форм наверший деревянных кладбищенских оград, которые зафиксированы по всей Карелии от села Михайловского на юге до Кестеньги на севере. Ромб на оградах встречается также в Поморье от Нюхчи и Колежмы до Гридина и Черной Реки. В Керети и Ковде на оградах встретилась также форма пятиугольника (обрезанного ромба) - отличительная черта декора множества культовых сооружений Карелии. Однако ограды в Поморье, как и в других карельских районах, были еще недавно относительно редки. К тому же в разных местах: в Сенной Губе на Выгозере, куда были переселены жители Карельского Острова, на Сямозере в Пряжинском районе и Юркострове Кондопожского района, а также в поморских селах Сухой Наволок и Ковда ромбами завершались оконечности намогильных крестов и их крыш. 
пустыни еще 5, на пригорке за пустынью 4, один из них на березе. На берегу озера напротив Иваньковской пустыни было обнаружено еще 5 деревьев с зарубками, причем две больших зарубки были сделаны на березах.
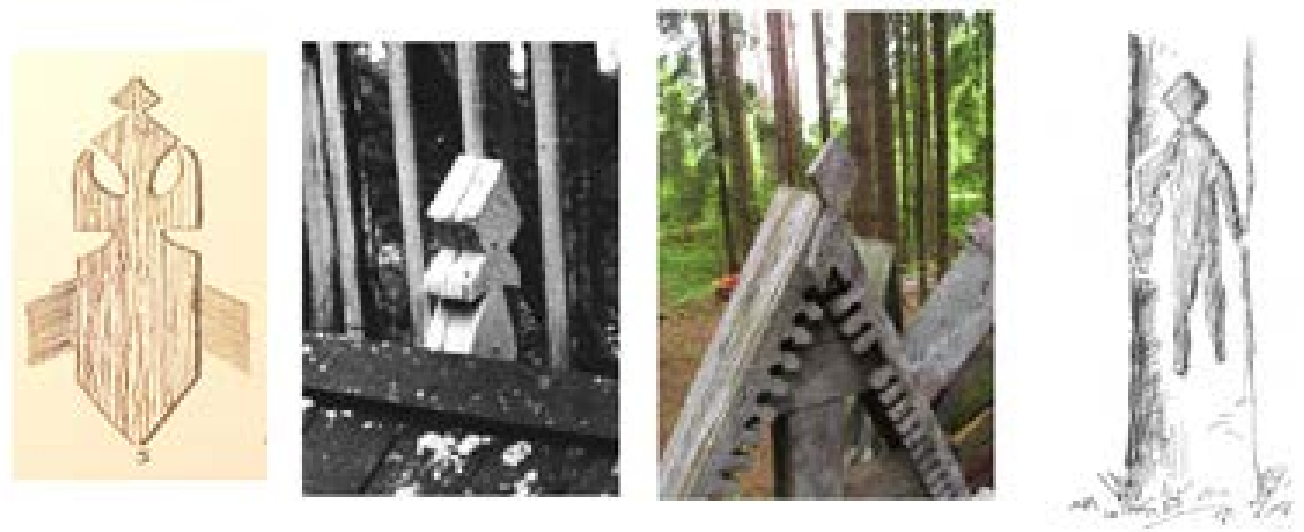

Рис. 11-14. Использование ромба в резьбе по дереву у карел (антропоморфные изображения) (фото автора Хайколя 1979; Нурмолицы 2014).

Fig. 11-14. The use of a rhombus in woodcarving among the Karelians (anthropomorphic images). (photo by the author, 1979 - Haikola and 2014 - Nurmoilu).

Примерно в 30 метрах от фундамента предполагаемого жилья на Иваньковской пустыне, в направлении на запад-северо-запад на старой сосне с развилистой вершиной и следами обрубания сучьев, Юрием Рыбаковым был обнаружен длинный широкий затес от самой земли (высота 1, 5 метра, ширина 40 см в самом широком месте) (рис. 15).
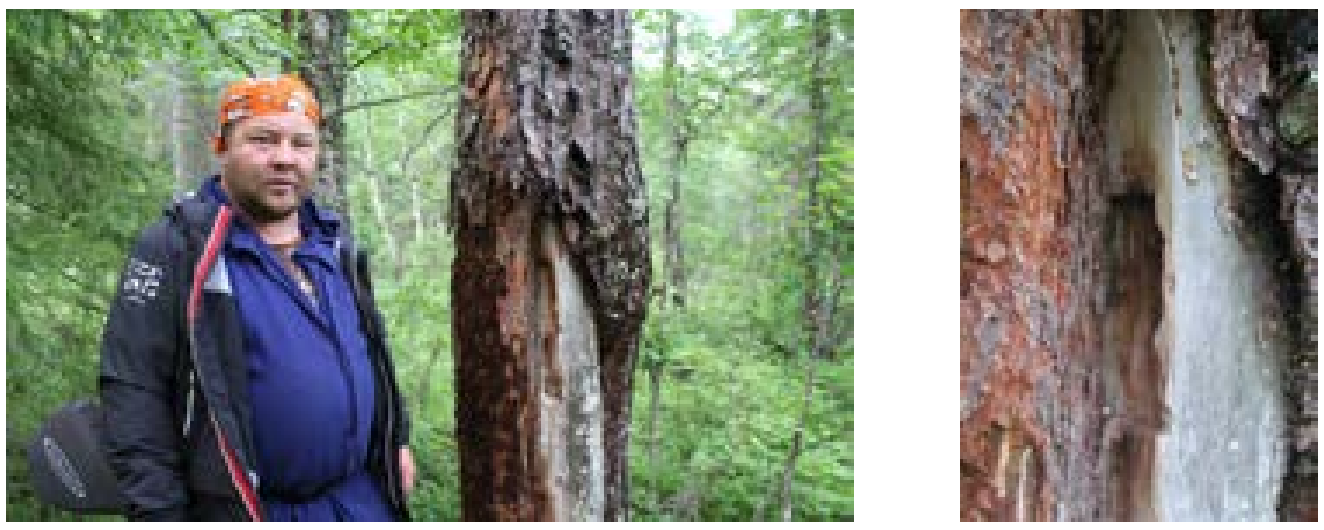

Рис. 15-16. Юрий Рыбаков на месте Иваньковской пустыни. Сосна-карсикко со следами врезанной в затес иконки-креста (фото автора, 2014).

Fig. 15-16. Yuri Rybakov in the place of the Ivankovskaya desert. Karsikko pine with traces of an embedded cross icon (photo by the author, 2014).

Вокруг зарубки происходило интенсивное зарастание и часть ее ушла под наплывы. Сейчас дерево вполовину толще того, что было при зарубании. В левом верхнем углу затеса сделана была еще одна зарубка длиной около 60 см - по самому затесу вырублена полость на левую сторону и верхняя часть большого затеса превратилась в острый «гребень» (рис. 16). 
На этой уходящей влево поверхности затеса вырезано основание для вставки туда креста - деревянного старообрядческого креста-иконки (как правило, на ней было изображение креста на горе Голгофе с головой Адама) выгорецкой работы, которые в старообрядческих районах Карелии (помимо частей медных складней) прибивались или утапливались в специально сделанные выемки на намогильных столбиках или на деревьях на кладбищах. Подобные крестики до последнего времени сохранялись на некоторых отдаленных кладбищах внутренних районов Карелии и Поморья, например, в Гридине (рис. 17). Высота креста-иконки 20, а ширина около 7 см. Направление примерно на запад, то есть то же, что и на кладбищах (учитывая, что крест ставился в ногах на востоке). В связи с этим фактом возникает вопрос: где в Иваньковской пустыне хоронили своих покойников? В любом случае, жители Иваньковской пустыни не брезговали народными обычаями, связанными с деревьями-карсикко.
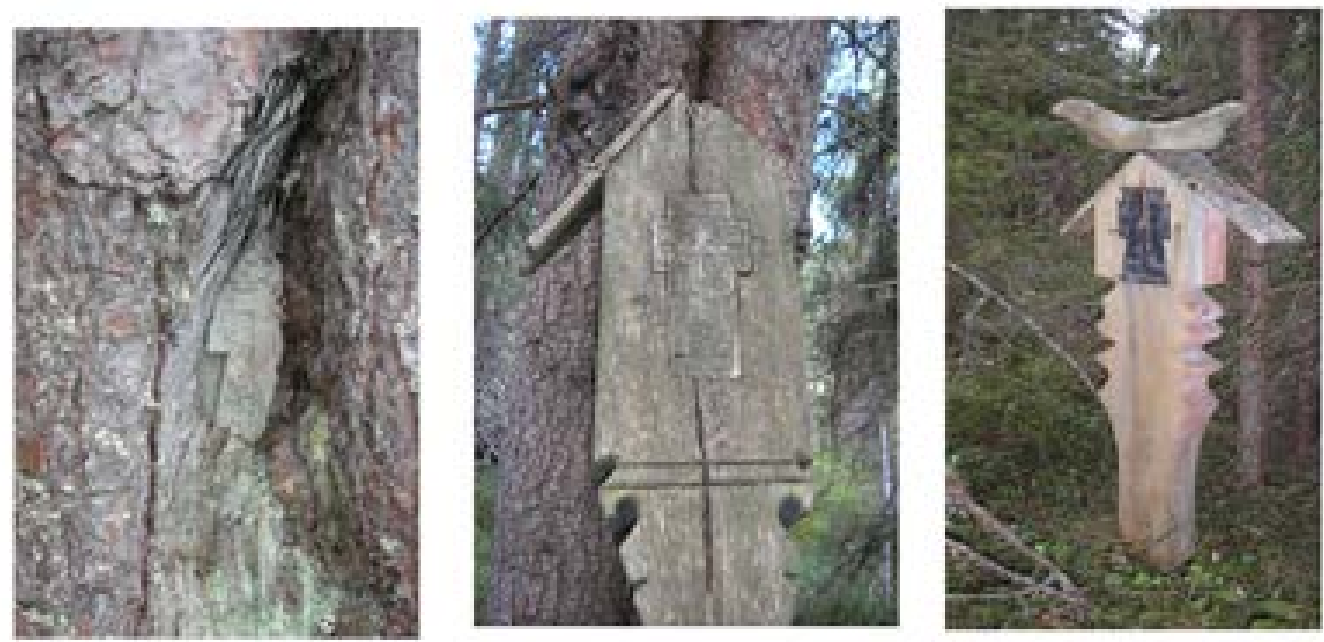

Рис. 17. Кресть-иконки, утопленные в дерево (слева) и в намогильные столбиь на кладбище поморской дер. Гридино (фото автора, 2009).

Fig. 17 (photo 17, 17a, 17b) Cross-icons embedded into a tree (left) and tomb columns in the cemetery of the Pomor village Gridino (photo by the author, 2009).

Известно, впрочем, что медные складни и их части раньше встречались не только на кладбищах, но и в деревьях на перекрестках дорог и особо опасных местах, где по поверьям местных жителей водилась нечистая сила. Вполне вероятно, что деревья эти были деревьями-карсикко и иконка играла нейтрализующую роль, причем нейтрализовалась не только нечистая сила, но и «языческий» обряд обрубания деревьев. На практике, как это часто бывало, в народном понимании эти религиозные атрибуты лишь усиливали друг друга. Народ использовал как языческие, так и христианские символы для защиты от духов и неведомых природных сил в равной степени активно.

\section{Источники и материалы}

Комшилов 1926 - Комшилов Я. А. Лопарские клейма. Мурманское Общество Краеведения (Из доклада, читанного на Общем собрании О-ва 5 декабря 1926 г.). Кольские карты. https://www.kolamap.ru/library/1926_komshilov.htm. 


\section{Научная литература}

Ефименко П. Юридические знаки // Журнал Министерства народного просвещения. 1874, 176, декабрь. С. 271-293. Приложение.

Золотарев Д.А. Карельские клейма // Известия РГО. М., 1924. Т. 56. Вып. 1. С. 141-153.

Историко-этнографический атлас Сибири / Под ред. М. Г. Левина, Л. П. Потапова. М.; Л.: Изд-во АН СССР, 1961. 498 с.

Косменко А.П. Традиционный орнамент финноязычных народов Северо-Запада России. Петрозаводск: Карельский научный центр РАН, 2002. 221 с.

Лавонен Н.А. Песенный фольклор кестеньгских карел. Петрозаводск: Карелия, 1989. 290 с.

Харузин Н. Русские лопари. Москва: Товарищество А.А. Левенсон, 1890. 482 с.

Blomstedt Y., Sucksdorff V. Karjalaisia rakennuksia ja koristemuotoja. Helsinki: Suomen muinaismuistoyhdistys, $1900.83 \mathrm{~s}$.

Ullberg U., Tavaststjerna A., Kekkonen J. Kansanomaisia rakennustapoja ja koristemuotoja Karjalasta kahden puolen rajaa. Helsinki: Suomen muinaismuistoyhdistys, 1929. 288 s.

\section{References}

Blomstedt Y., V. Sucksdorff. 1900. Karjalaisia rakennuksia ja koristemuotoja [Karelian buildings and decorative forms]. Helsinki: Suomen muinaismuistoyhdistys.

Efimenko P. 1874. Yuridicheskie znaki [Legal signs]. Zhurnal Ministerstva narodnogo prosveshcheniia 176 (december): 271-293. Prilozhenie.

Levin M.G., Potapov L.P. (eds.) Istoriko-etnograficheskii atlas Sibiri. 1961 [Historical and ethnographic atlas of Siberia], edited by. Moscow; Leningrad: Izd-vo AN SSSR.

Kharuzin N. 1890. Russkie lopari [Russian Lapps]. Moscow: Tovarishchestvo A.A. Levenson.

Kosmenko A.P. 2002. Traditsionnyi ornament finnoiazychnykh narodov Severo-Zapada Rossii [Traditional ornament of the Finnish-speaking peoples of the North-West of Russia]. Petrozavodsk: Karel'skii nauchnyi tsentr RAN.

Lavonen N.A. 1989. Pesennyi fol'klor kesten'gskikh karel [Song folklore of the Kesteng Karelians]. Petrozavodsk: Kareliia.

Ullberg U., A. Tavaststjerna and J. Kekkonen. 1929. Kansanomaisia rakennustapoja ja koristemuotoja Karjalasta kahden puolen rajaa [Folk building methods and decorative forms from Karelia on the two sides of the border]. Helsinki: Suomen muinaismuistoyhdistys.

Zolotarev D. A. 1924. Karel'skie kleima [Karelian brands]. Izvestiia Russkogo Geograficheskogo obshestva, 56 (1), 141-153. 